\title{
Characterization and Effects of Municipal Solid Waste Landfill Leachate on Ground Water Quality, Case Study of Gandhi Nagar City, Gujarat
}

\author{
Krupa Engineer ${ }^{\text {* }}$ \\ ${ }^{1 *}$ Department of Civil Engineering, SAL Engineering \& Technical Institute, Ahmedabad, Gujarat, India
}

\begin{abstract}
Disposal of solid waste without any proper practice is one of the most common techniques in developing countries. The percolating water passed through the wastes becomes contaminated and dissolved soluble organic and in organic as well as suspended particles. The contaminated fluid i.e. leachate percolates through soil and affects the soil quality as well as ground water. Factors like precipitation, runoff, infiltration, evaporation, ambient temperature, waste composition, waste density, moisture content of waste, depth of waste fill affects the production of leachate from the landfill. In this research leachate characterization was studied which was generating from municipal solid waste dumping site of Gandhinagar city of Gujarat along with ground water samples. Various physico-chemical parameters like $\mathrm{pH}$, Electrical conductivity, Total dissolved solids,Chemical oxygen demands; Alkalinity and Calcium (Ca 2+) were analyzed and reported and were found more than the prescribed limits. The ground water near to dump site was found to be polluted and cannot be used directly for potable and non potable uses without having further treatment.
\end{abstract}

Keywords: Solid waste, Leachate, Pollution, Ground Water, Landfill.

\section{Introduction}

Solid waste is dumped on soil in most developing countries without acceptable sanitary land-filling methods. Precipitation infiltrating the solid waste disposed of on land mixes with the liquids already trapped in the waste crevices and solid waste leaching compounds. The resulting leachate includes inorganic and organic solutes dissolved. The leachate created spreads into the soil over time and changes the water's physicochemical features [1]. Major components such as calcium, magnesium, potassium, nitrogen and ammonia, trace metals such as iron, copper, manganese, chromium nickel, lead and organic compounds such as phenols, polyaromatic hydrocarbons, acetone, benzene, toluene, chloroform etc. The concentration of these in water and leachate relies on the waste structure [3]. During the leachate flow through the soil, some of the pollutants may be absorbed into the soil media. Areas close to landfills are more likely to contaminate groundwater due to the potential source of leachate pollution from the neighbouring dumping site. Such groundwater

*Corresponding Author: e-mail: krupa.engineer@sal.edu.in Tel-+91-9574979861

ISSN 2320-7590

(C) 2019 Darshan Institute of Engg. \& Tech., All rights reserved contamination puts local groundwater resource users and the natural environment at significant danger. In latest years, the effect of landfill leachate on surface and groundwater has resulted in a number of researches and has gained considerable significance owing to dramatic population growth [1]. Many methods can be used to evaluate contamination of groundwater and surface water. It can be evaluated through mathematical modelling either through the experimental determination of the impurities or their assessment. Once groundwater becomes contaminated, it is very hard and in some instances even impossible to fully restore its quality [4].

Water pollution is water bodies (e.g. lakes, rivers, oceans, aquifers, and groundwater) contamination. Water pollution happens when, without proper therapy, pollutants are discharged directly or indirectly into water bodies. Pollution from water affects crops and organisms that live in these water bodies [9]. The impact damages individual species, species populations, and also harms natural biological communities in almost all instances. Surface water is interrelated with groundwater. Surface water flows through the soil and turns into groundwater. On the other hand, 
groundwater can also feed sources of ground water. Landfills are regarded one of the main groundwater threats [10].

Leachate is contaminated liquid that emanates from the bottom of solid waste such as landfills and includes both soluble organic and inorganic compounds and suspended particles. The flow of leachate may boost or reduce depending on the weather. The discharge of landfill leachate may cause severe environmental issues [5]. Leachate can percolate through landfill liners and subsoil that cause soil and surface water resources to be polluted. A landfill is intended to safeguard the environment from damaging contamination through the provision of suitable liner to minimize the migration of contaminates in leachate. Sanitary landfill leachate generation is a complicated mixture of physical, chemical and biological processes [6]. Whereby waste age has an impact on landfill efficiency which produces leachate. Pollution of surface water and ground water are the significant potential environmental effects associated with solid waste landfill leachate. Probably the most severe environmental impact on landfills is the danger of groundwater pollution because historically most landfills were constructed without engineered liners and leachate collection and treatment scheme [11]. It is generally recognized that landfills are subjected to at least four decomposition stages. An original stage of aerobic and anaerobic acid, an original phase of methanogenic acid, a stable phase of methanogenic acid [12]. The aim of this research is (i) to determine the quality of leachate generated, (ii) to study the effect of those on ground water quality of landfill site of Gandhinagar, Gujarat.

\section{Study Area}

Gandhinagar is Gujarat's eighth municipal corporation with a population of over 2 lakhs and an area of $56 \mathrm{sq}$. km. The town is experiencing both a significant building / infrastructure boom and a continuous rise in population. It is a increasing

centre of education, IT. The Gandhinagar Municipal Corporation (GMC) offers some of the main services to Gandhinagar residents such as Gandhinagar, solid waste management, Gandhinagar medical transportation are some of the main facilities. To provide all citizens with effective service and smooth administration. GMC split its operations into six wards [8].

Some of the waste in a house was prevalent and repetitive in nature, such as paper (9\%), plastic bags (9\%), private grooming (8\%), vegetables and fruit (9\%), sanitary pads (7\%), unconsumed food (8\%), FMCG packaging (6\%), cardboard packaging (3\%), private regenerative (9\%) and household dusting waste (9\%). Waste from diapers, wipes, nappies (4\%), etc., specifically applied to certain types of households where a tiny kid was present. Fragile products have been treated very carefully and thus such waste has been rarely produced; examples are broken glassware (2\%) useless CD-DVDs and handsets (2\%). Rubber wasteslippers (1\%), leather waste-shoes (2\%), tin containers (4\%), plastic containers $(6 \%)$ and rags $(2 \%)$ were exhausted item waste. Thus, there were drastically different frequencies of prevalent, particular, brittle and exhausted waste [8].

\section{Materials and Methods}

Leaching from a landfill differs extensively according to the era of the landfill and the type of waste it includes. It generally includes dissolved material as well as suspended material. Leachate generation is primarily triggered by precipitation through waste deposited in a landfill. The percolating water becomes contaminated once it is in touch with decomposing solid waste, and if it then flows out of the waste material it is called leachate. During this decomposition, a broad variety of other products including methane, carbon dioxide and a complicated combination of organic acids, aldehydes, alcohols are generated. Leachate generation hazards can be mitigated by correctly designed and engineered waste locations, such as those built on geologically impermeable materials or sites using impermeable geomembranes or engineered clay liners. Leachate specimens were gathered along with ground water specimens from strong waste dumping locations. Various parameters like $\mathrm{pH}$, Electrical conductivity, Total dissolved solids, Chemical oxygen demand, alkalinity, Ca concentration were measured for collected samples [2].

Table 1. Physico-chemical analysis of leachate

\begin{tabular}{|c|c|c|c|c|c|c|}
\hline Parameters & $\begin{array}{c}\text { Sample- } \\
1\end{array}$ & $\begin{array}{c}\text { Sample- } \\
2\end{array}$ & $\begin{array}{c}\text { Sample- } \\
3\end{array}$ & $\begin{array}{c}\text { Sample- } \\
4\end{array}$ & $\begin{array}{c}\text { Sample- } \\
5\end{array}$ & $\begin{array}{c}\text { Sample- } \\
6\end{array}$ \\
\hline $\mathrm{pH}$ & 7.92 & 7.84 & 8.93 & 8.85 & 8.92 & 8.98 \\
\hline $\begin{array}{c}\text { Condu- } \\
\text { ctivity } \\
(\mu \mathrm{s} / \mathrm{cm})\end{array}$ & 4320 & 4328 & 4308 & 4420 & 4310 & 4324 \\
\hline Colour & $\begin{array}{c}\text { Dark } \\
\text { black }\end{array}$ & $\begin{array}{c}\text { Dark } \\
\text { black }\end{array}$ & $\begin{array}{c}\text { Dark } \\
\text { black }\end{array}$ & $\begin{array}{c}\text { Dark } \\
\text { black }\end{array}$ & $\begin{array}{c}\text { Dark } \\
\text { black }\end{array}$ & $\begin{array}{c}\text { Dark } \\
\text { black }\end{array}$ \\
\hline TDS (ppm) & 2890 & 2840 & 2760 & 2784 & 2892 & 2892 \\
\hline $\begin{array}{c}\text { COD } \\
(\mathrm{mg} / \mathrm{L})\end{array}$ & 8090 & 8065 & 6389 & 6432 & 6328 & 6339 \\
\hline $\begin{array}{c}\text { Alkalinity } \\
(\mathrm{mg} / \mathrm{L})\end{array}$ & 7460 & 7432 & 6284 & 6392 & 6398 & 6421 \\
\hline $\begin{array}{c}\text { Calcium } \\
(\mathrm{mg} / \mathrm{L})\end{array}$ & 290 & 290 & 210 & 225 & 232 & 230 \\
\hline
\end{tabular}


Table 2. Characteristics of groundwater samples

\begin{tabular}{|c|c|c|c|c|c|c|}
\hline Parameters & $\begin{array}{c}\text { Sample- } \\
1\end{array}$ & $\begin{array}{c}\text { Sample- } \\
2\end{array}$ & $\begin{array}{c}\text { Sample- } \\
3\end{array}$ & $\begin{array}{c}\text { Sample- } \\
4\end{array}$ & $\begin{array}{c}\text { Sample- } \\
5\end{array}$ & $\begin{array}{c}\text { Sample- } \\
6\end{array}$ \\
\hline $\mathrm{pH}$ & 7.82 & 7.69 & 7.80 & 7.34 & 7.83 & 7.92 \\
\hline $\begin{array}{c}\text { Condu- } \\
\text { ctivity } \\
(\mu \mathrm{s} / \mathrm{cm})\end{array}$ & 1867 & 1865 & 1698 & 1690 & 1695 & 1687 \\
\hline TDS (ppm) & 1653 & 1653 & 1780 & 1763 & 1772 & 1846 \\
\hline $\begin{array}{c}\mathrm{COD} \\
(\mathrm{mg} / \mathrm{L})\end{array}$ & 11.6 & 9.4 & 12.3 & 8.9 & 13.7 & 12.5 \\
\hline $\begin{array}{c}\text { Alkalinity } \\
(\mathrm{mg} / \mathrm{L})\end{array}$ & 750 & 680 & 640 & 633 & 638 & 643 \\
\hline $\begin{array}{c}\text { Calcium } \\
(\mathrm{mg} / \mathrm{L})\end{array}$ & 120 & 165 & 145 & 134 & 122 & 167 \\
\hline
\end{tabular}

Table 3. Desirable limits of different parameters for drinking water as per BIS [7]

\begin{tabular}{|c|c|}
\hline Parameters & Desirable limits \\
\hline $\mathrm{pH}$ & $6.5-8.0$ \\
\hline Conductivity $(\mu \mathrm{s} / \mathrm{cm})$ & $2 \mathrm{~ms} / \mathrm{cm}$ \\
\hline TDS $(\mathrm{ppm})$ & $500 \mathrm{ppm}$ \\
\hline COD $(\mathrm{mg} / \mathrm{L})$ & - \\
\hline Alkalinity $(\mathrm{mg} / \mathrm{L})$ & $200-600 \mathrm{mg} / \mathrm{L}$ \\
\hline Calcium $(\mathrm{mg} / \mathrm{L})$ & 7 \\
\hline
\end{tabular}

Table 4. The disposal of treated leachate shall follow the following standards

\begin{tabular}{|c|c|c|c|c|}
\hline $\begin{array}{c}\text { Sr. } \\
\text { No }\end{array}$ & Parameter & \multicolumn{3}{|c|}{ Standards (Mode of } \\
Disposal )
\end{tabular}

(Source: Ministry of Environment and Forests Notification 25th September, 2000)

\section{Results and Discussion}

$4.1 \mathrm{pH}$ : The $\mathrm{pH}$ of the waste site leachate was varied from 7.84 to 8.98 . The $\mathrm{pH}$ is mainly governed by a number of chemical reactions. Degradation of organic materials to generate carbon dioxide and tiny amounts of ammonia is the significant response. To form ammonium ions and carbonic acid, these dissolve in the leachate. The carbonic acid is easily dissociated to generate cations of hydrogen and anions of bicarbonate. This affects the system's $\mathrm{pH}$ level. Furthermore, leachate $\mathrm{pH}$ is also affected by the partial pressure of the carbon dioxide gas produced which is contact with the leachate. The $\mathrm{pH}$ range between 6.0 and 9.0 appears to protect the lives of freshwater fish and invertebrates in the bottom dwelling.

The $\mathrm{pH}$ values observed in between 7.34 to 7.92 in the ground water specimens. These differences were probably due to numerous variables such as the infiltration of rainwater and the impacts of dilution. In addition, the $\mathrm{pH}$ values may also be affected by the influx of contaminants from natural and anthropogenic operations such as percolation of solid waste leachate and other land uses. However, within what would be deemed a fairly ordinary band was these $\mathrm{pH}$ values. When compared with the IS10500 recommended range for $\mathrm{pH}$ in drinking water (6.5-8.0) are within the acceptable range.

4.2 Electrical Conductivity and Total Dissolved Solids: These parameters are usually affected by the complete quantity of organic and inorganic dissolved materials current in the solution and are used to show the degree of salinity and leachate mineral content. Furthermore, total mineral content reflects the leachate's strength and overall polluting load. Due to the presence of potassium, sodium, chloride, nitrate, sulfate and ammonia salts, the salt content in the leachate. As a result of organic matter degradation, the leachate sample appears to have high values $(\mathrm{EC}=4308$ to $4420 \mu \mathrm{S}$ / $\mathrm{cm})(\mathrm{TDS}=2760$ to $2892 \mathrm{ppm})$. When comparing water samples with the IS10500, it is discovered that the recommended conductivity range and TDS in drinking water are in unacceptable range i.e. (TDS= 1653 to $1846 \mathrm{ppm}$ ) $(\mathrm{EC}=1687$ to $1867 \mu \mathrm{S} / \mathrm{cm})$.

4.3 Chemical Oxygen Demand: The test of chemical oxygen demand (COD) is frequently used to assess the quantity of organic compounds in water indirectly. Most COD apps determine the quantity of organic pollutants discovered in wastewater, making COD a helpful wastewater quality metric. It is given in $\mathrm{mg} / \mathrm{L}$, indicating the amount of oxygen consumed per litre of solution. More the worst COD concentration is the sewage character. According to the central pollution board, if treated sewage is disposed of in the freshwater body, the COD disposal limit is $250 \mathrm{mg} / \mathrm{L}$. The COD is 6328 to $8090 \mathrm{mg} / \mathrm{L}$ for the collected leachate sample, shows more organic matter present in samples. The COD for ground water varied from 9.4 to $12.5 \mathrm{mg} / \mathrm{L}$, which indicates a slight presence of organic matter in ground water samples. 
4.4 Alkalinity: Bicarbonate, carbonate and hydroxyl ion are categorised as the different forms of alkalinity. In wastewater treatment it is essential: coagulation, softening, assessment of water buffering ability. However, total alkalinity values are often discovered to be substantially greater than natural waters for landfill leachate values. This is due to the process of biochemical decomposition and dissolution within a site of land filling and disposal. The biodegradation procedures of organic matter within the waste mass generate a substantial quantity of bicarbonate, representing dissolved carbon dioxide as well as being the main elements of alkalinity. The leachate sample was discovered to have considerably elevated alkalinity (6284 to $7460 \mathrm{mg} / \mathrm{L}$ ). The elevated alkalinity found in this research represents the amount of the method of biodegradation within the locations of disposal. Significant quantities of ash and slag are present in landfill locations due to the combustion of wood, agricultural residues and peat. These elements in leachate are known to significantly boost alkalinity. Water sample discovered to have elevated concentration (633 to $750 \mathrm{mg} / \mathrm{L}$ ) may have health effects owing to the decreased solubility of many heavy metals. In the water sample, it could generate an unpleasant odor that is unacceptable to many customers. Therefore, the elevated alkalinity values found in this research indicate contamination of the groundwater.

4.5 Calcium: Calcium, magnesium, sodium and potassium constituents are generally considered to be typically major cations present in leachate. The concentration of these cations in leachate, derived from the waste material through mass transfer procedures, is particular to the structure of the waste volume and the prevailing stability stage in the landfill. Sodium and potassium are not significantly impacted by landfill site microbiological activity. In plant physiology, these ions play a significant function and are most probably derived from vegetable residues and domestic waste. In increased concentration of potassium in groundwater, leachate pollution is often regarded as an indicator. Calcium concentrations were noticeably high in collected leachate sample (210 to $290 \mathrm{mg} / \mathrm{L})$ and for ground water sample (120 to $167 \mathrm{mg} / \mathrm{L})$.

\section{Conclusions}

In this research, the primary environmental issue is the impact of leachate from landfills on water quality.

- Leachate was defined by elevated content of organic and inorganic chemicals suggesting that the dumped waste is predominantly municipal waste.

- It found to have significantly high salinity and alkalinity as reflected in its conductivity values, TDS, alkalinity and $\mathrm{pH}$. Consequently, leachate was considered to contain substantial contaminant loads that pose a threat to the groundwater aquifer at the base.
- The impact of leachate is seen in neighbouring water bodies based on the distinct chemical parameters in landfill and surrounding water bodies.

- Leachate migration to land and water resources tends to occur. This can lead to soil, ground water and subsurface water resources being contaminated. Algae development in the bodies of water is the confirmation of the impact of leachate on the bodies of water.

\section{Recommendations}

Sanitary waste disposal is a significant measure of waste disposal, and often the only one. Appropriate landfill design and operation has to take into account the multi-barrier principle with various autonomous design and operation obstacles. Landfill design begins with the choice of an appropriate geological and hydrogeological landfill site. To isolate the waste from the environment, both the bottom liner system and the ground liner system. The lining systems incorporate lining components and layers of drainage. Leachate and landfill gas collection as well as therapy are needed in relation to the lining processes.

The operation of landfills comprises organizational and technical steps. Good organization of landfills begins with the definition of waste to be disposed of, followed by an entry control. An extensive compaction of waste is very essential, minimizing environmental hazards and saving the quantity of landfill. Biological waste pre-treatment reduces the pollution of leachate and the generation of landfill gas. Landfill site monitoring will allow early detection of damage to the environment.

In the transition era from' waste dumping' to' contemporary landfill technology,' domestic officials can support regional and local authorities by drawing up rules on regional circumstances, training and supply of equipment. In order to recognize the most hazardous landfills, the old dump sites should be closed step by step following a risk assessment procedure. The surface of the landfill should finally be covered with soil, whereas a real surface Liner system is the better solution.

\section{References}

1. Aderemi Adeolu O, O. A. (2011). Assessment of groundwater contamination by leachate near a municipal solid waste landfill. African Journal of Environment Science and Technology, Vol. 5(11), pp. 933-940.

2. APHA (1998). Standard Methods for Examination of Water and Waste water, 19th edition, American Public Health Association, Washington, DC. Brock T.D. and Madigan 
M.T.Biology of Microorganisms. 5th edition. Prentice Hall International.

3. Ahmed. F.A. (2012). Ground water pollution Threats of Solid Waste Disposal in Urban Kano, Nigeria: Evaluation and Protection Strategies, Doctor of Philosophy, The University of Manchester, England

4. Bhalla. B., Saini. M.S. and Jha. M.K. (2012). Characterization of Leachate from Municipal Solid Waste (MSW) Landfilling Sites of Ludhiana, India: A Comparative Study, Jl. Of Engineering Research and Applications. Vol.2, Issue 6, 732-745

5. Chain. E.S.K and Dewalle. E.B. (1976). Sanitary landfill leachate and their treatment, Journal of Environmental Engineering Division, ASCE, 108(EE2), 411.

6. Hui, T.S. (2005). Leachate Treatment by Floating Plants in Constructed Wetland Master's Thesis, Universiti Teknologi Malaysia, Malaysia.

7. IS: 10500(1992). "Drinking water; drinking water specification,” Bureau of Indian Standards.

8. Jigna Trivedi and Bindiya Kunal Soni (2015). A Study on Household Waste Management Practices in Gandhinagar City, NMIMS Management Review Volume XXVII, 103-121.

9. Naveen. B.P, Anil kumar sharma, Sivapualliah. P.V., Sitharam. T.G., Ashwath Narayan. M.S. (2013). Characterisitcs of the Leachate from MSW Landfill, Bangalore , Silver Jubilee Celebrations of Indian Chapter of IGS International Symposium "Geosynthetics India2013", 24-25 October, New Delhi, India, pp.139145.

10. Pande G, Sinha A, Agrawal S. (2015). Impacts of leachate percolation on ground water quality: $A$ case study of Dhanbad city. Global Nest J 17: 162174.

11. Peter .K, Morton A. B, Alix P. R, Anders B, Anna. L, and Thomas H.C. (2002). Present and Long-Term Composition of MSW Landfill Leachate: A Review, Critical Reviews in Environmental Science and Technology, 32(4), 297-336.

12. Robinson. A.H. (2005). Landfill leachate treatment, Journal of Membrane Technology, 6-12. 